\title{
Pendugaan Erosi Tanah dan Arahan Rehabilitasi Lahan berbasis SIG di DAS Wai Ela Negeri Lima Jazirah Leihitu Pulau Ambon
}

\author{
GIS Based Soil Erosion Estimation and Proposed Land Rehabilitation in Wai Ela \\ Watershed Negeri Lima, Jazirah Leitimur Ambon Island
}

\author{
Sisilia Wariunsora ${ }^{1}$, Rafael M. Osok ${ }^{2, *}$, Silwanus M. Talakua ${ }^{2}$ \\ ${ }^{1}$ Program Studi Agroteknologi, Fakultas Pertanian, Universitas Pattimura, Jl. Ir. M. Putuhena, Kampus Poka \\ Ambon 97233, Indonesia \\ ${ }^{2}$ Jurusan Budidaya Pertanian, Universitas Pattimura, Jl. Ir. M. Putuhena, Kampus Poka Ambon 97233, Indonesia \\ *E-mail Penulis Korespondensi: rafael.osok@faperta.unpatti.ac.id
}

Tanggal submisi: 06 Februari 2019; Tanggal penerimaan: 31 Januari 2020

\begin{abstract}
The occurrence of soil erosion in Wai Ela Watershed is related to natural factors such as geology, soil types, slope steepness, and land uses. This study aimed to estimate soil erosion rates and their spatial distribution in Wai Ela watershed, and the results were used to establish land rehabilitation practices. The study used a survey method with a flexible grid observation distance, and field data collection was conducted on 15 sampling areas representing 72 land units. The annual soil erosion rates of Wai Ela watershed were estimated by using RUSLE and GIS, and the results were corrected with 0,2547 (Talakua and Osok's correction factor). The proposed land rehabilitation practices were established based on the tolerable soil erosion (T) values and CP maximum. The study results showed that the average annual erosion rates in Wai Ela watershed vary from light erosion $(8,14 \mathrm{t} / \mathrm{ha} / \mathrm{yr})$ to very heavy erosion $(381,70 \mathrm{t} / \mathrm{ha} / \mathrm{yr})$, while the tolerable soil erosion rates range from 4,60 t/ha/yr to 24t/ha/yr. The proposed land rehabilitation practices include enrichment of the existing unprotected areas (bare lands) with forest and fruit trees, planting cover crops and grasses, and mulching on agricultural land.
\end{abstract}

Keywords: correction factor 0,2547, land rehabilitation practices, RUSLE, Wai Ela watershed

\section{ABSTRAK}

Erosi pada DAS Wai Ela terjadi akibat faktor alam yaitu geologi, jenis tanah, panjang dan kemiringan lereng dan penggunaan lahan. Tujuan penelitian adalah menduga besarnya erosi di DAS Wai Ela, dan menetapkan arahan rehabilitasi lahannya. Metode yang digunakan adalah survei dengan tipe observasi fleksible grid dan pengumpulan data lapangan dilakukan pada 15 sampel area yang mewakili 72 satuan lahan. Besarnya erosi dihitung menggunakan metode RUSLE dan hasilnya dikoreksi dengan factor 0,2547 , dan dipetakan menggunakan program SIG. Hasil penelitian menunjukkan bahwa rrosbi di DAS Wai Ela berkisar dari sangat ringan $(8,14$ ton/ha/thn) hingga erosi sangat berat (381,70 ton/ha/thn), sedangkan erosi yang dapat dibiarkan atau nilai T berkisar dari 4,6 ton/ha/thn hingga 24 ton/ha/thn. Arahan rehabilitasi lahan yang disarankan adalah melakukan pengkayaan pada lahan-lahan yang terbuka dengan tanaman hutan dan buahbuahan, menanam tanaman penutup tanah dan rumput pada lahan yang miring dan penggunaan mulsa serasah/jerami, pada lahan-lahan pertanian.

Kata kunci: DAS Wai Ela, faktor koreksi 0,2547, usulan rehabilitasi lahan, RUSLE

\section{PENDAHULUAN}

Ambon merupakan pulau yang terdiri dari dua jazirah, yaitu Jazirah Leitimur, dimana terletak kota Ambon, dan Jazirah Leihitu yang sebagian besar wilayahnya masuk dalam kabupaten Maluku Tengah. Secara alami, Pulau Ambon dibentuk dari satu kesatuan daerah aliran sungai (DAS) sehingga memiliki karakter khas yaitu pulau dengan banyak sungai dengan ukuran kecil. Selain itu, lebih $70 \%$ dari wilayah Pulau Ambon merupakan daerah perbukitan dengan topografi terjal hingga sangat terjal, sehingga salah satu masalah di wilayah Pulau Ambon adalah terbatasnya lahan yang sesuai untuk dimanfaatkan dan ancaman kerusakan tanah akibat erosi yang tinggi bila lahan digunakan tanpa menerapkan aspek-aspek konservasi tanah. Talakua dan 
Osok (2019) mengatakan bahwa penggunaan lahan yang baik perlu memperhatikan karakteristik lahan seperti kondisi tanah dan kemiringan lereng, serta harus dimanfaatkan sesuai dengan kemampuan lahannya agar tidak memicu terjadinya erosi dan degradasi lahan. Penelitian yang dilakukan di Jazirah Leitimur (Manuputty, 2017; Osok et al., 2018; Tahir, 2011) menunjukkan bahwa erosi yang terjadi pada DAS-DAS di wilayah Kota Ambon didominasi oleh tingkat bahaya erosi berat hingga sangat berat dengan jumlah kehilangan tanah berkisar dari 250-300 ton/ha/tahun. DAS Wai Ela yang terletak di Jazirah Leihitu, desa Negeri Lima, Kabupaten Maluku Tengah merupakan salah satu DAS yang mendapat perhatian serius secara nasional, khususnya setelah terjadi longsor yang menyebabkan terbentuknya danau alami di sungai Wai Ela pada tahun 2012. Pada tahun 2013 danau alam ini jebol karena meluapnya air sungai akibat curah hujan dan aliran permukaan yang tinggi diikuti banjir bandang yang melanda hilir sungai. Fenomena diatas memberi gambaran bahwa lingkungan DAS Wai Ela mempunyai kerentanan yang tinggi terhadap kerusakan. Penelitian ini mengkaji karakteristik lahan, menduga besarnya erosi dan distribusinya secara spasial, dan membuat arahan rehabilitasi lahan untuk mengurangi besarnya erosi yang terjadi di DAS Wai Ela.

\section{METODE PENELITIAN}

Penelitian ini menggunakan metode survei berbasis unit lahan sebagai peta kerja lapangan yang didesain berdasarkan hasil tumpang susun (overlay) 4 komponen utama yaitu: kelas topografi, formasi geologi, tanah dan pola penggunaan lahan. Peta kelas topografi dibuat dari peta citra SRTM skala 1:100.000, peta geologi diperoleh dari peta geologi lembar Ambon Maluku skala 1:250.000 (Direktoral Jenderal Geologi dan Sumber Daya Mineral, 1994), peta tanah diperoleh dari hasil penelitian peta tanah DAS Wai Ela skala 1: 30.000 (Balai Pengelolaan DAS Waehapu Batu Merah, 2012), peta penggunaan lahan diperoleh dari peta tahun 2015 skala 1: 250.000 (Balai Pemantauan Kawasan Hutan Wilayah IX Maluku, 2015) dan peta penggunaan lahan DAS Wai Ela skala 1:30.000 (Balai Pengelolaan DAS Waehapu Batu Merah, 2012). Total unit lahan di lokasi penelitian adalah 72 satuan lahan. Pengumpulan data lapangan dilakukan pada sampel area yang mewakili semua unit lahan mengikuti jalur-jalur pengamatan yang telah ditetapkan pada setiap sampel area. Jumlah sampel area yang digunakan untuk pengamatan adalah 15 unit. Besarnya erosi dihitung pada setiap unit lahan dengan menggunakan metode RUSLE, yaitu $\mathrm{A}=\mathrm{R} \times \mathrm{K} \times \mathrm{LS} \times$ $\mathrm{C} \times \mathrm{P}$, dan hasil perhitungan erosi selanjutnya dikoreksi menggunakan model degradasi lahan akibat erosi oleh, D $=0,2547 \times \mathrm{R} \times \mathrm{K} \times \mathrm{LS} \times \mathrm{C} \times \mathrm{P}$ (Talakua dan Osok, 2017), dimana D adalah besarnya degradasi lahan (ton/ha/thn), $\mathrm{R}$ adalah nilai erosivitas hujan (ton.m/ha/cm-hujan), $\mathrm{K}$ adalah nilai erodibilitas tanah, LS adalah nilai indeks faktor topografi terutama panjang dan kemiringan lereng, $\mathrm{C}$ adalah nilai indeks faktor tanaman atau vegetasi, dan $\mathrm{P}$ adalah nilai indeks faktor tindakan konservasi tanah. Semua parameter RUSLE dipetakan dalam format raster SIG.

\section{HASIL DAN PEMBAHASAN}

\section{Faktor kehilangan tanah RUSLE}

\section{Erosivitas Hujan (R)}

Erosivitas hujan atau nilai $\mathrm{R}$ menunjukkan kemampuan hujan menyebabkan erosi. Gambar 1 menunjukkan bahwa nilai erosivitas (R) di DAS Wai Ela Negeri Lima adalah $2520.86 \mathrm{t} . \mathrm{m} / \mathrm{ha} / \mathrm{cm}$ hujan. Erosivitas hujan bulanan tertinggi terjadi pada bulan Juni (567.73 t.m/ha/cm hujan), dan terendah pada bulan November (35.01 t.m/ha/cm hujan). Artinya, jika pada bulan juni curah hujan yang jatuh sebesar $10 \mathrm{~mm}$ pada areal seluas 1 ha akan berpotensi menyebabkan degradasi tanah akibat erosi sebesar 567,73 ton, dengan asumsi jika faktor lainnya dalam keadaan konstan. Gelagay dan Minale (2016) mengatakan bahwa faktor R mengindikasikan dua hal yaitu dampak dari hujan dan besar dan laju aliran permukaan. Oleh sebab itu, semakin besar intensitas hujan semakin besar total aliran permukaan dan jumlah sedimen yang tererosi (Mohamadi dan Kavian, 2015).

\section{Erodibilitas Tanah (K)}

Erodibilitas tanah atau nilai $\mathrm{K}$ merupakan nilai yang menggambarkan kepekaan atau mudah tidaknya suatu tanah mengalami erosi. Hasil penelitian menunjukkan bahwa nilai K tertinggi di DAS Wai Ela adalah 0,33 , yaitu agak tinggi yang ditemukan pada tanah aluvial eutrik seluas 13,96 ha. Hal ini menunjukkan bahwa $0,93 \%$ dari luas DAS rentan atau mudah tererosi karena tanah aluvial memiliki persentase pasir sangat halus dan debu yang cukup tinggi, dan persen liat yang rendah, sehingga stabilitas struktur tanahnya rendah. Sebaliknya nilai $\mathrm{K}$ yang terkecil adalah 0,12 atau tergolong rendah ditemukan secara dominan pada tanah kambisol distrik (876,66 ha) dan litosol (214,59 ha) yang mengindikasikan bahwa sekitar 73\% dari luas DAS Wai Ela memiliki kepekaan yang rendah atau lebih tahan terhadap erosi. Tanah kambisol dan litosol memiliki komposisi debu dan liat yang lebih tinggi dibandingkan tanah aluvial sehingga struktur tanah yang terbentuk lebih stabil dan mampu menahan daya rusak butiran hujan. Ashari (2013) mengatakan bahwa bila nilai M meningkat akibat \% pasir sangat halus dan debu yang tinggi, maka nilai $\mathrm{K}$ akan meningkat atau tanah tersebut lebih peka terhadap erosi atau mudah mengalami erosi. Sebaran erodibilitas tanah (nilai K) disajikan pada Gambar 2.

\section{Panjang dan Kemiringan Lereng (LS)}

Nilai LS merupakan nilai yang menggambarkan pengaruh topografi yaitu kombinasi Panjang (L) dan kemiringan lereng (S) terhadap besarnya erosi. Semakin miring sudut kemiringan dan panjang lereng, erosi semakin besar. Hasil penelitian ini menunjukkan bahwa 
nilai LS yang paling tinggi di DAS Wai Ela adalah 12 yang ditemukan pada lereng curam (45-65\%) dan sangat curam (> 65\%) seluas 209,21 ha (14\%), sedangkan nilai LS yang paling kecil adalah 0,25 ditemukan pada lereng 0-3\% (datar) dan 3-8\%, (landai) seluas 853,79 ha $(57,15 \%)$. Hasil penelitian ini menunjukkan bahwa lokasi di DAS Wai Ela yang mempunyai nilai LS tinggi mempunyai ancaman erosi semakin besar. Hal ini terjadi karena semakin miring lereng kecepatan aliran air akan semakin cepat sehingga pengikisan permukaan tanah semakin besar (Devhataa, 2015; Zhang et al., 2017). Sebaran nilai LS disajikan pada Gambar 3.

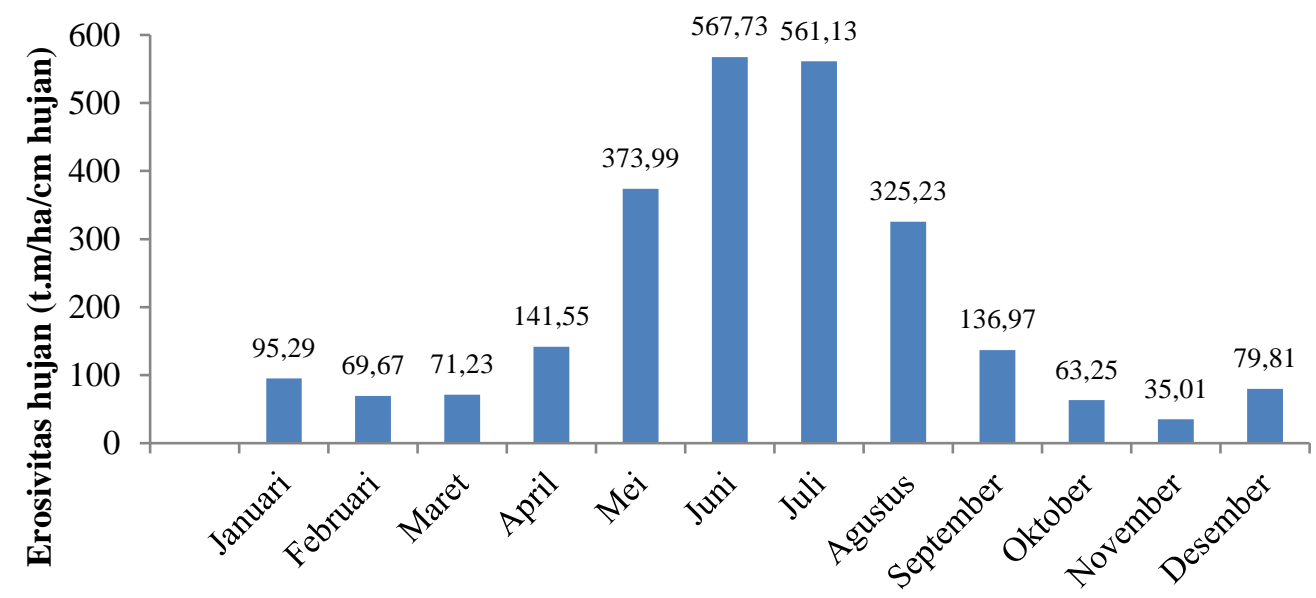

Bulan

Gambar. 1. Sebaran erosivitas hujan di DAS Wai Ela

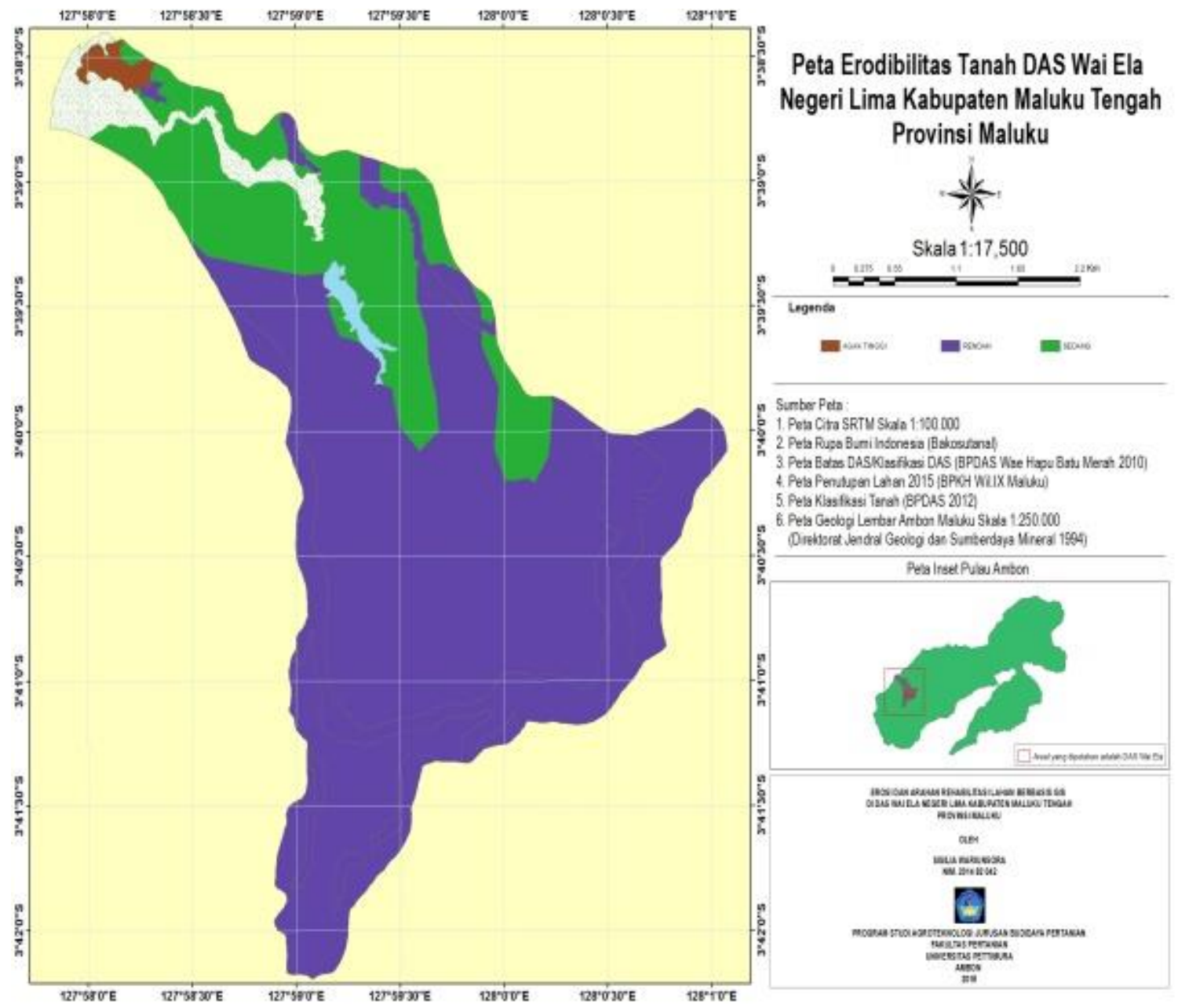

Gambar 2. Sebaran erodibilitas tanah di DAS Wai Ela 


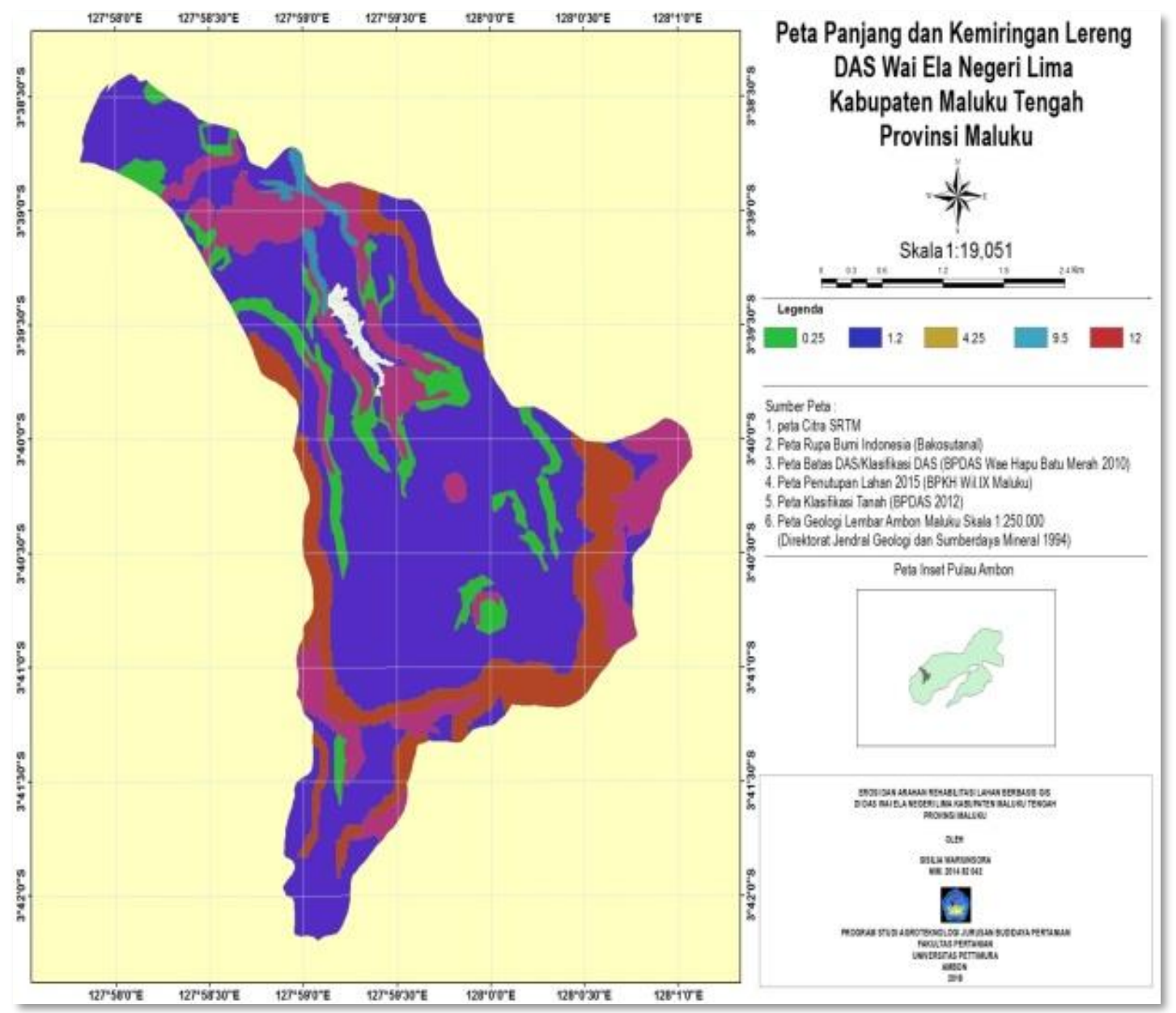

Gambar 3. Sebaran panjang dan kemiringan lereng (LS) di DAS Wai Ela

\section{Faktor Pengelolaan Tanaman (C) dan Konservasi Tanah (P)}

Faktor pengelolaan tanaman (nilai C) sangat berperan melindungi permukaan tanah dari pukulan butir hujan (faktor erosivitas) sedangan faktor konservasi tanah (nilai P) seperti terasering, penanaman sejajar kontur, saluran pembuangan air dibuat untuk mengatur arah aliran permukaan sehingga jumlah dan laju aliran permukaan dapat dikurangi. Pada DAS Wai Ela tidak ditemukan Tindakan konservasi sehingga untuk semua penggunaan lahan nilai $\mathrm{P}$ adalah 1 . Hasil penelitian ini menunjukkan bahwa terdapat 12 tipe penggunaan lahan di DAS Wai Ela, dengan nilai $C$ berkisar 0,005-1. Nilai $\mathrm{C}$ tertinggi (1) ditemukan pada pemukiman dengan luas 9,31 ha $(0,62 \%)$ dan lahan terbuka 67,37 ha $(4,5 \%)$ mengindikasikan bahwa kedua penggunaan lahan ini mempunyai ancaman terjadinya erosi yang besar, sedangkan ancaman erosi yang paling kecil ditemukan pada penggunaan lahan hutan sekunder $(243,54$ ha atau $16,30 \%$ ) dengan nilai $\mathrm{C}=0,005$. Pengunaan lahan yang paling luas adalah kebun campuran, seluas 1075,55 ha (72\%) dengan nilai $\mathrm{C}=0,2$. Kebun campuran di lokasi penelitian merupakan penggunaan lahan dengan kombinasi vegetasi hutan, buah-buahan, perkebunan, dan tanaman rempah (cengkeh dan pala) sehingga mempunyai kerapatan tutupan dan stratifikasi tanaman atas dan bawah yang ba (nilai $\mathrm{C}=0,2$ ). Oleh sebab itu dari aspek pengelolaan tanaman, DAS Wai Ela mempunyai ancaman erosi yang kecil. Hasil ini didukung Talakua dan Osok (2018) yang mengatakan bahwa kerapatan vegetasi atas mempunyai korelasi negatif dengan degradasi tanah pada penggunaan lahan kebun campuran $(r=-0,92)$, yang berarti bahwa semakin tinggi kerapatan tutupan atas degradasi tanah semakin kecil atau sebaliknya semakin berkurang kerapatan tutupan atas degradasi tanah akibat erosi semakin meningkat. Adanya tutupan atas dan stratifikasi vegetasi yang baik mengurangi dampak pukulan air hujan (erosivitas) dan pengaruh topografi terhadap aliran permukaan menjadi kecil (Panagos et al., 2015). Sebaran penggunaan lahan disajikan pada Gambar 4.

\section{Tingkat Bahaya Erosi (TBE)}

Analisis tingkat bahaya erosi (TBE) menunjukkan bahwa sebaran TBE di DAS Wai Ela berkisar dari kelas sangat berat sampai kelas sangat ringan. Besarnya erosi pada kelas erosi sangat ringan adalah 8,14 ton/ha/thn, erosi ringan 11,28 ton/ha/thn, erosi sedang 59,23 ton/ha/thn, rosi berat 177,72 ton/ha/thn dan sangat berat adalah 381,70 ton/ha/thn. Tabel 1 menunjukkan bahwa DAS Wai Ela telah mengalami degradasi dengan ratarata erosi yang terjadi berkisar $8,14-733,06 \mathrm{t} / \mathrm{ha} / \mathrm{thn}$ 
dengan TBE sangat ringan - sangat berat. TBE yang paling luas ditemukan di DAS Wai Ela adalah erosi ringan yaitu 733,06 ha $(49,07 \%)$, dan yang paling sempit adalah erosi sangat berat seluas 159 ha $(10,64 \%)$ (Tabel 1 dan Gambar 5).

TBE sangat ringan menyebar pada daerah dengan lereng datar, landai, agak miring, miring dan agak curam pada jenis tanah kambisol eutrik, penggunaan lahan kebun campuran, semak belukar jarang dan padat, dan hutan sekunder, dan memiliki karakteristik tanah tekstur lempung, struktur granular halus, permeabilitas agak lambat dengan kandungan bahan organik rendah.

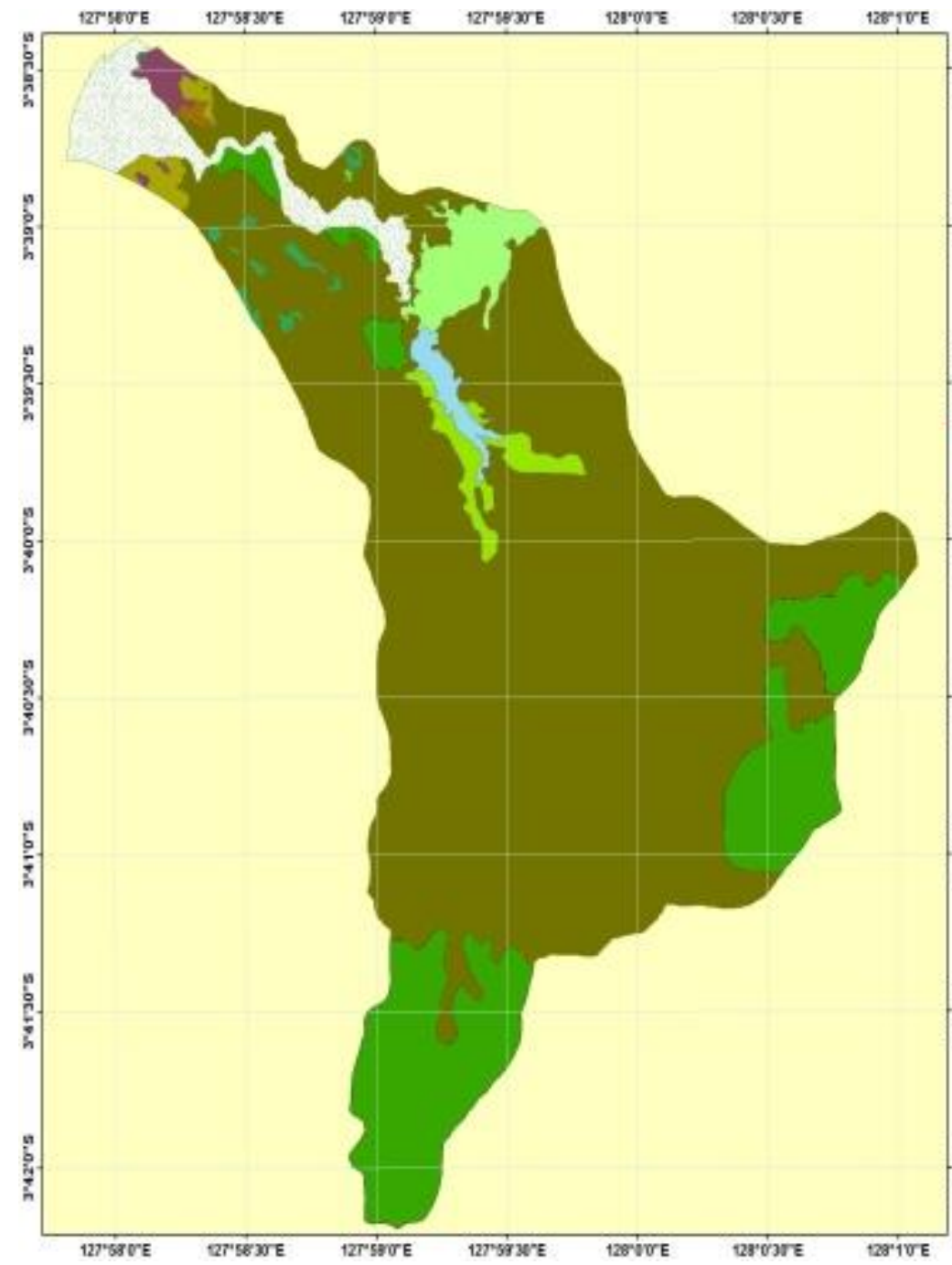

\section{Peta Penggunaan Lahan DAS Wai Ela Negeri Lima Kabupaten Maluku Tengah} Provinsi Maluku

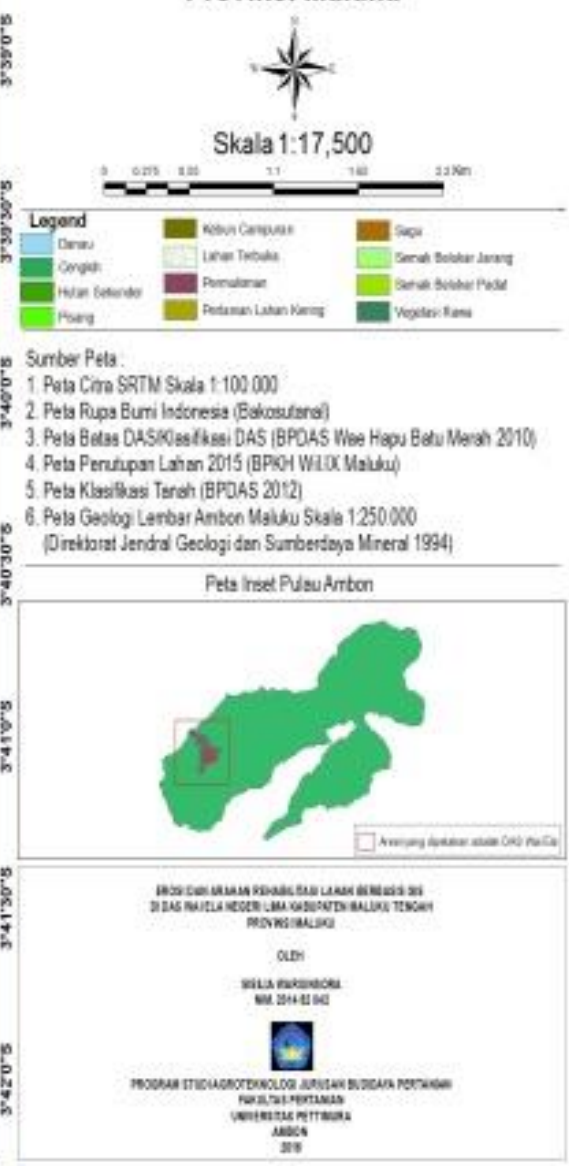

Gambar 4. Sebara penggunaan lahan di DAS Wai Ela

Tabel 1. Tingkat bahaya erosi di DAS Wai Ela

\begin{tabular}{llcccc}
\hline No & Kelas Erosi & $\begin{array}{c}\text { Kisaran besar erosi } \\
(\mathrm{t} / \mathrm{ha} / \mathrm{thn})\end{array}$ & $\begin{array}{c}\text { Erosi rata-rata } \\
\text { (t/ha/thn) }\end{array}$ & Luas (Ha) & Luas $(\%)$ \\
\hline 1 & Sangat Berat & $244,76-535,00$ & 381,70 & 159,00 & 10,64 \\
2 & Berat & $7,73-463,46$ & 177,72 & 170,11 & 11,39 \\
3 & Sedang & $18,20-159,56$ & 59,23 & 167,70 & 11,23 \\
4 & Ringan & $0,095-46,93$ & 11,28 & 733,06 & 49,07 \\
5 & Sangat Ringan & $0,25-14,08$ & 8,14 & 189,78 & 4,70 \\
6 & Koluvium & - & - & 60,97 & 0,89 \\
7 & Danau & - & - & 13,25 & 100 \\
\hline
\end{tabular}

Sumber: Hasil Analisis 2018. 


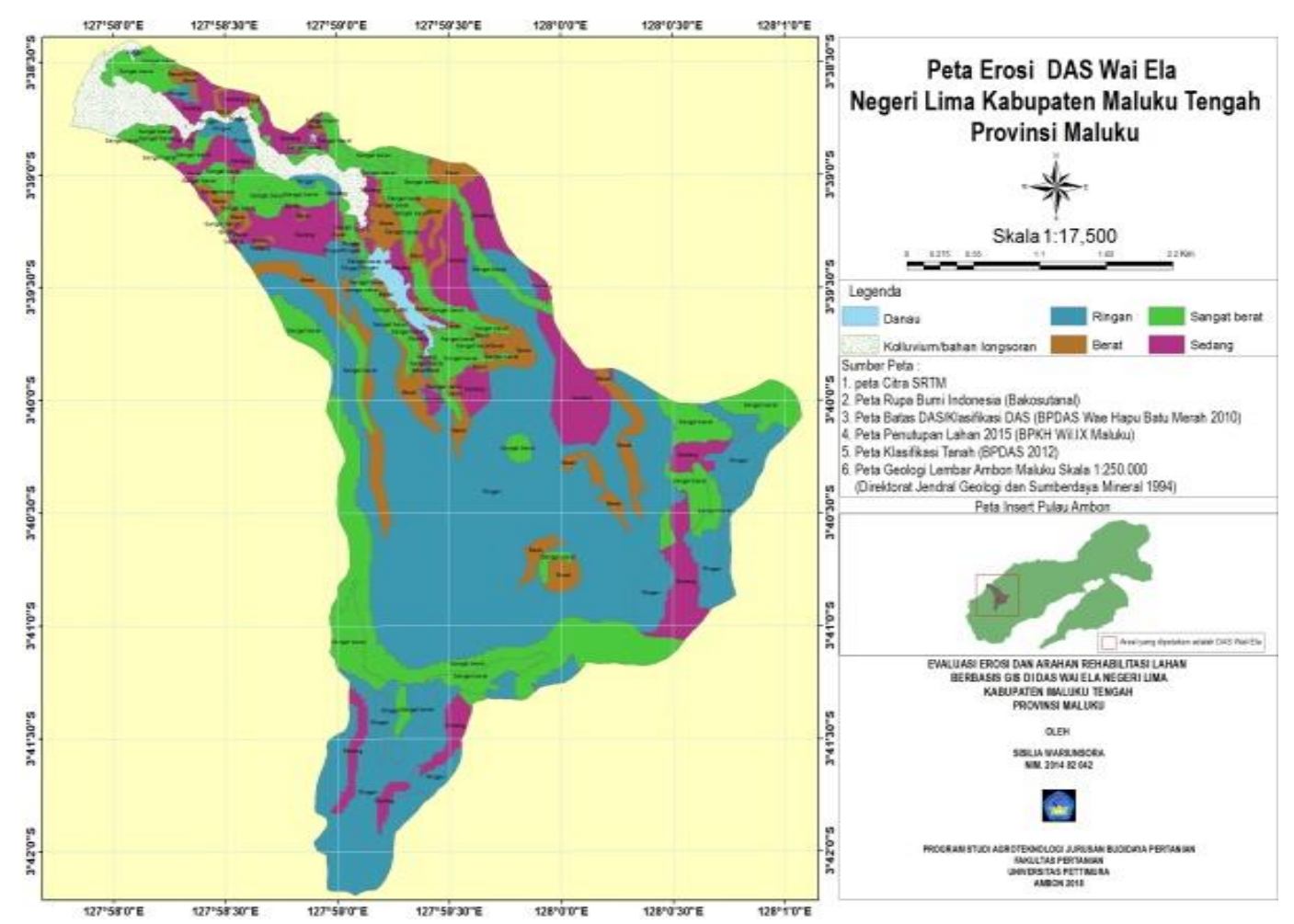

Gambar 5. Sebaran tingkat bahaya erosi di DAS Wai Ela

TBE ringan terdapat pada daerah dengan lereng datar, landai, agak miring, miring dan agak curam, penggunaan lahan sagu, pertanian lahan kering, cengkih, pisang, kebun campuran, semak belukar padat dan hutan sekunder, dan memiliki karakteristik tanah tekstur lempung, liat berdebu, dan lempung liat berpasir, struktur tanah masif, granuler halus dan granuler sedang, permeabilitas lambat dan agak lambat dengan kandungan bahan organik rendah sampai tinggi. TBE sedang terdapat pada daerah dengan lereng datar, landai, agak miring dan miring, penggunaan lahan pemukiman, pertanian lahan kering, lahan terbuka, cengkih,semak belukar jarang dan padat dan kebun campuran, dan memiliki karakteristik tanah tekstur lempung dan lempung liat berpasir, struktur tanah granuler halus, granuler sedang dan gumpal, permeabilitas agak lambat dengan kandungan bahan organik rendah sampai. TBE berat terdapat pada lereng agak miring sampai sangat curam, penggunaan lahan pemukiman, cengkih, semak belukar jarang dan padat, kebun campuran dan pertanian lahan kering, dan karakteristik tanahnya tekstur lempung, lempung liat berpasir dan lempung berpasir, struktur tanah granuler halus, granuler sedang dan gumpal, permeabilitas agak lambat dengan kandungan bahan organik rendah sampai sedang. TBE sangat berat terdapat pada lereng agak curam sampai sangat curam, penggunaan lahan semak belukar jarang, cengkih, dan kebun campuran, dan memiliki tanah dengan tekstur tanah lempung dan lempung berpasir, struktur tanah granuler halus permeabilitas profil agak lambat dengan kandungan bahan organik rendah.

\section{Hubungan Faktor Erosi dengan Besarnya Erosi}

Hasil analisis hubungan faktor-faktor penyebab erosi di DAS Wai Ela menghasilkan model regresi pangkat dengan hubungan yang signifikan pada tingkat kepercayaan $95 \%$, yang diindikasikan dengan nilai $P_{\text {value }}$ $=0,000 *$. Faktor-faktor yang mempunyai pengaruh lebih dominan adalah faktor erodibilitas tanah $(\mathrm{K})$, panjang dan kemiringan lereng (LS) dan penggunaan lahan (C), dengan persamaan regresi $\log \mathrm{E}=2,81+1,00 \log \mathrm{K}+$ $1,00 \log \mathrm{LS}+1,00 \log \mathrm{C}$, dan koefisien determinasi $\mathrm{R}^{2}=$ 0,99 atau $99 \%$. Hasil ini menunjukkan bahwa semakin meningkatnya nilai faktor erodibilitas tanah (K), panjang dan kemiringan lereng (LS) dan penggunaan lahan (C), maka akan meningkatkan besarnya kehilangan tanah dan tingkat bahaya erosi di DAS Wai Ela. Untuk faktor erodibilitas tanah $(\mathrm{K})$, hubungannya menunjukkan pengaruh nyata $\left(P_{\text {value }}=0,000 *\right)$ terhadap besarnya erosi di DAS Wai Ela pada tingkat signifikansi $95 \%$ dengan model non linier (eksponensial) $\mathrm{E}=194,4 \mathrm{~K}^{1,426}$. Gambar 6 menunjukkan bahwa semakin tinggi nilai $\mathrm{K}$ maka bahaya erosi semakin meningkat, dengan asumsi faktor erosivitas hujan (R), panjang dan kemiringan lereng (LS), penggunaan lahan (C) dan upaya konservasi $(\mathrm{P}) \mathrm{di}$ lokasi penelitian berada pada kondisi konstan.

Faktor topografi (panjang dan kemiringan lereng (LS) juga menunjukkan pengaruh nyata $\left(P_{\text {value }}=0,000 *\right)$ terhadap besarnya erosi pada tingkat signifikansi $95 \%$ dengan model non linier (eksponensial) yaitu $\mathrm{E}=$ $54,87 \ln (\mathrm{LS})+86,57$, dimana semakin tinggi nilai LS maka bahaya erosi semakin meningkat, dengan asumsi faktor erosivitas hujan (R), erodibilitas tanah (K), penggunaan lahan $(\mathrm{C})$ dan upaya konservasi $(\mathrm{P})$ di lokasi 
penelitian berada pada kondisi konstan (Gambar 7). Sedangkan faktor penggunaan lahan $(\mathrm{C})$ menunjukkan pengaruh nyata $\left(P_{\text {value }}=0,000 *\right)$ terhadap besarnya erosi di DAS Wai Ela pada tingkat signifikansi $95 \%$ dengan model non linier (eksponensial) yaitu $\mathrm{E}=120,3 \mathrm{C}^{0,903}$, dimana semakin tinggi nilai $\mathrm{C}$ maka bahaya erosi semakin meningkat, dengan asumsi faktor erosivitas hujan (R), erodibilitas tanah (K), panjang dan kemiringan lereng (LS) dan upaya konservasi (P) di lokasi penelitian berada pada kondisi konstan (Gambar 8).

\section{Nilai Toleransi Erosi (T)}

Nilai $\mathrm{T}$ sangat berperan dalam menentukan apakah sudah terjadi kerusakan tanah akibat erosi (erosi dipercepat) atau belum. Bila erosi aktual lebih besar dari erosi yang masih dapat ditoleransikan maka telah terjadi erosi dipercepat, sebaliknya jika lebih kecil dari nilai $\mathrm{T}$ maka erosinya masih dalam batas alamiah dan belum terjadi erosi dipercepat.

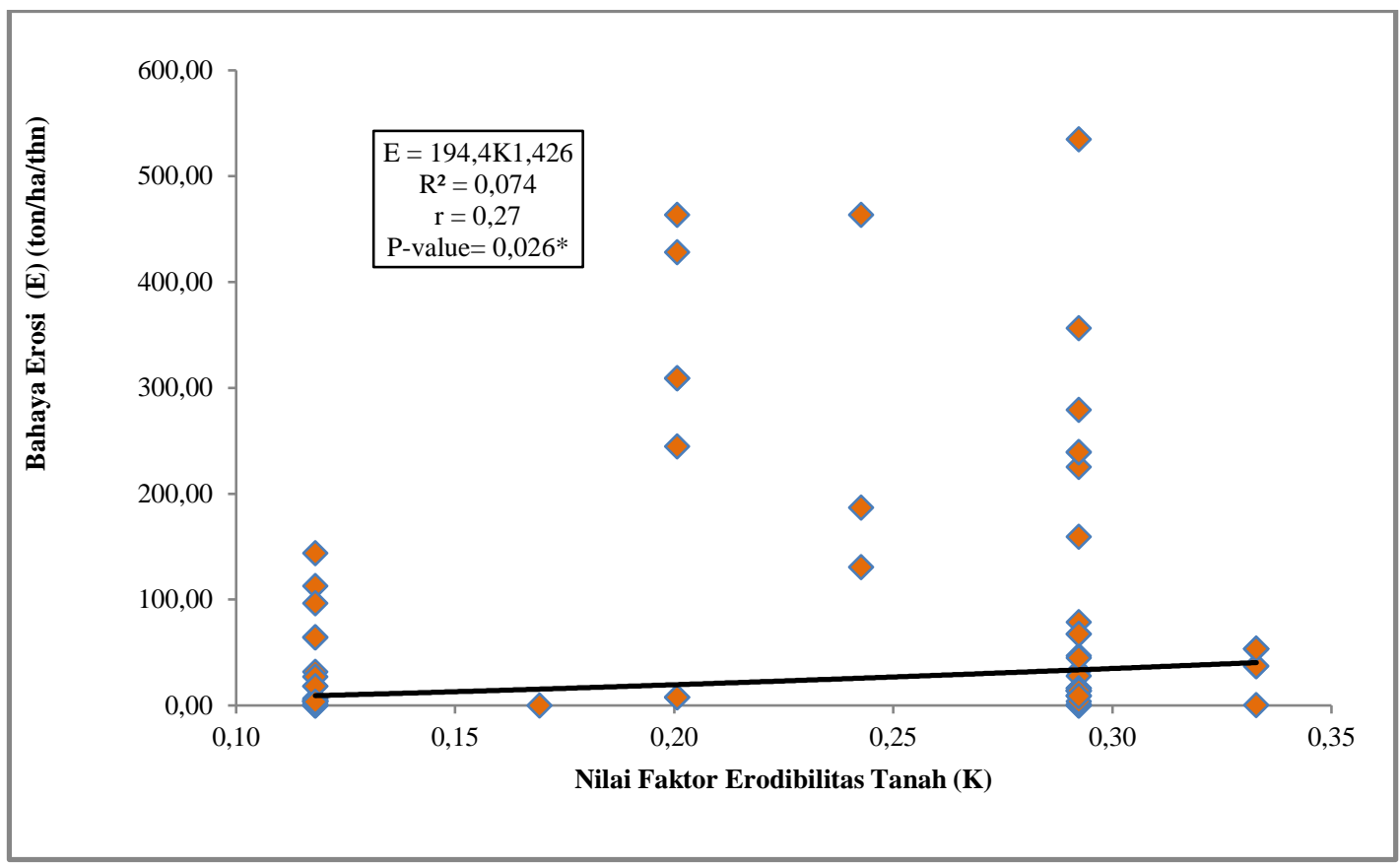

Gambar 6. Hubungan Faktor erodibilitas (K) dengan besarnya erosi di DAS Wai Ela

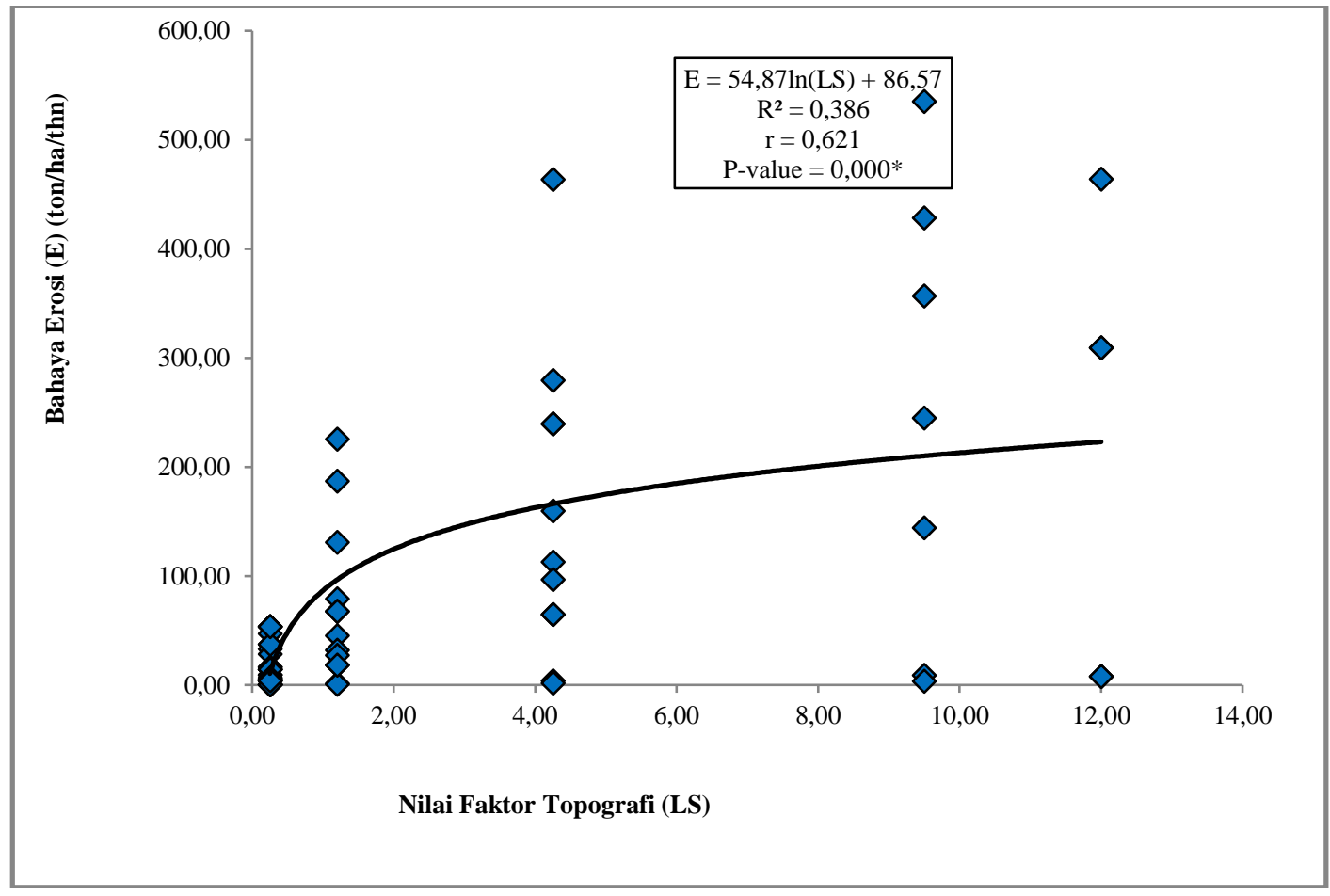

Gambar 7. Hubungan faktor panjang dan kemiringan lereng dengan besarnya erosi di DAS Wai Ela 


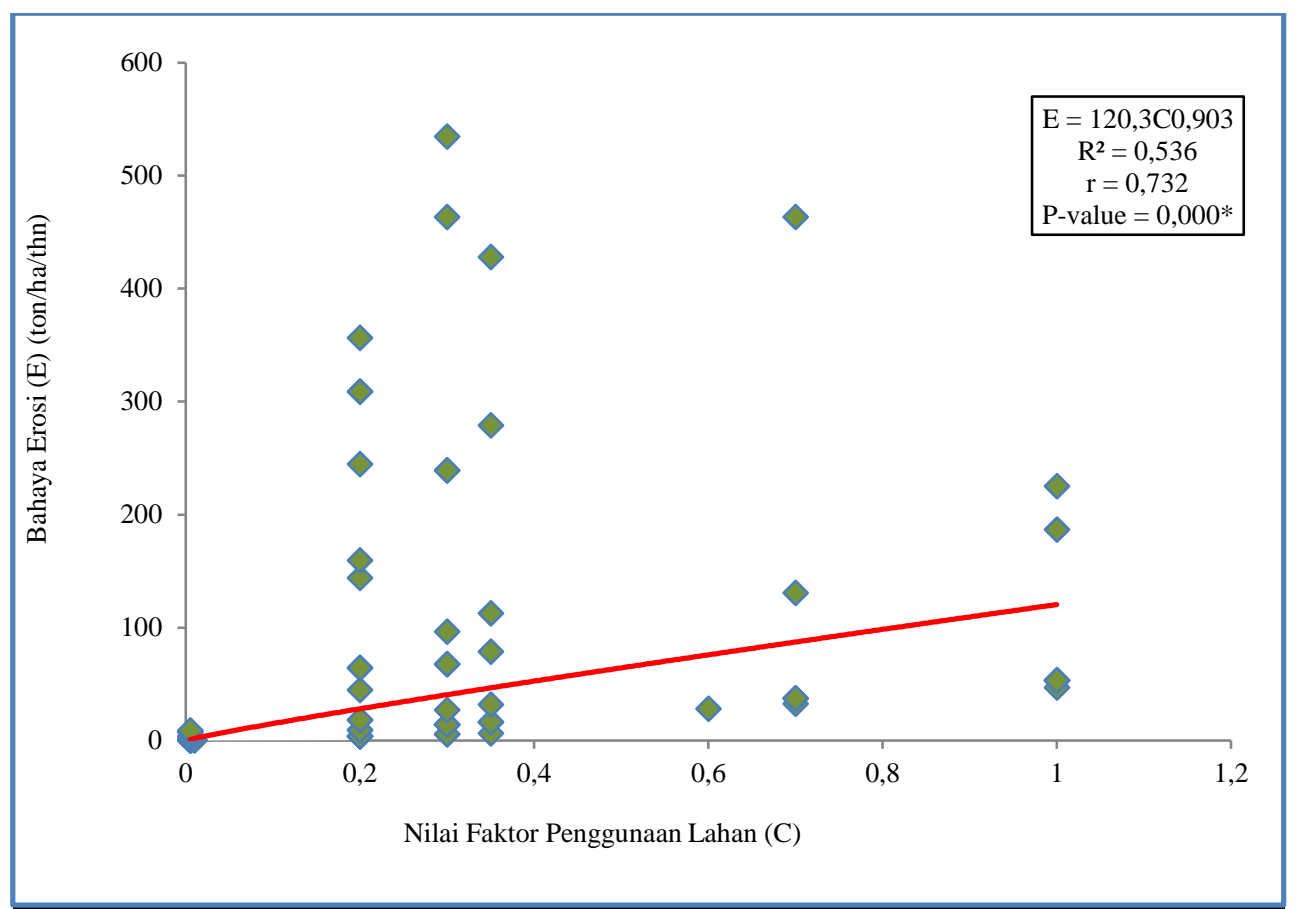

Gambar 8. Hubungan faktor pengelolaan tanaman dengan besarnya erosi di DAS Wai Ela

Hal ini akan berpengaruh dalam menentukan tindakan pengendalian kerusakan tanah akibat erosi. Semakin kecil nilai $\mathrm{T}$, berarti tindakan pengendalian erosi semakin serius dan semakin berat. Nilai T di DAS Wai Ela berkisar antara 0,4-2 $\mathrm{mm} / \mathrm{thn}$ atau 4,60-24,00 ton/ha/thn dengan permeabilitas lapisan bawah (sub soil) lambat-sedang, kedalaman solum tanah sangat dangkaldalam, dan bobot isi tanah $1,00-1,20 \mathrm{~g} / \mathrm{cm}^{3}$. Unit lahan yang memiliki nilai $\mathrm{T}$ sebesar 4,60 ton/ha/thn identik dengan kedalaman tanah yang harus dijaga $0,4 \mathrm{~mm} / \mathrm{thn}$. Hal ini disebabkan karena memiliki solum tanah sangat dangkal, di samping permebilitas subsoil agak lambat dan bobot isi tanah $1,15 \mathrm{~g} / \mathrm{cm}^{3}$. Sedangkan yang memiliki nilai T 24,00 ton/ha/thn identik dengan kedalaman tanah yang harus terus dijaga adalah sebesar $2,0 \mathrm{~mm} / \mathrm{thn}$. Hal ini disebabkan karena memiliki solum tanah dalam, permebilitas subsoil sedang dan bobot isi tanah 1,20 $\mathrm{g} / \mathrm{cm}^{3}$. Sebaran nilai $\mathrm{T}$ disajikan pada Tabel 2 dan Gambar 9.

\section{Arahan Rehabilitasi Lahan}

Arahan rehabilitasi lahan untuk DAS Wai Ela ditentukan berdasarkan nilai $\mathrm{CP}$ maksimum sebagai rujukan faktor $\mathrm{C}$ dan faktor $\mathrm{P}$ yang disarankan, dan nilai toleransi erosi (nilai $\mathrm{T}$ ) dengan mempertimbangkan/ mempertahankan penggunaan lahan dan vegetasi asli yang ada, sehingga arahan rehabilitasi lahan yang diusulkan mampu menurunkan degradasi lahan akibat erosi dibawah toleransi erosi sebesar 12 sampai 16.96 ton/ha/thn.

1. Pola rehabilitasi lahan pada penggunaan lahan Cengkih, yaitu melalui pengkayaan dengan pohon hutan dan buah-buahan, penanaman tanaman penutup tanah dengan kerapatan sedang-rapat (CP maks 0,092-0,161), dan penanaman rumput dalam strip pada lahan dengan lereng landai-miring (CP maks 0,005, 0,009, 0,019 dan 0,033).

2. Pola rehabilitasi lahan pada penggunaan lahan hutan sekunder, yaitu tetap dipertahankan (untuk CP maks. berkisar 0,002 sampai 0,161), dan pengkayaan dengan pohon hutan lokal (CP maks 0,001).

Tabel 2. Nilai toleransi erosi yang diperbolehkan

\begin{tabular}{|c|c|c|c|c|c|c|c|c|}
\hline No. & Tanah & $\begin{array}{c}\text { Permeabilitas } \\
\text { lap bwh }\end{array}$ & Kls dalam profil & $\begin{array}{l}\text { Bobot isi } \\
\text { (g/cm3) }\end{array}$ & $\begin{array}{c}\text { Nilai T } \\
(\mathrm{mm} / \mathrm{thn})\end{array}$ & $\begin{array}{c}\text { Nilai T } \\
\text { (ton/ha/thn) }\end{array}$ & $\begin{array}{l}\text { Luas } \\
\text { (ha) }\end{array}$ & $(\%)$ \\
\hline 1. & Lithic Udorthents & Agak Lambat & Sangat Dangkal & 1,15 & 0.4 & 4,60 & 214,59 & 14,36 \\
\hline 2. & Typic Dystrudepts & Agak Lambat & Sedang & 1,00 & 1.2 & 12,00 & 876,66 & 58,68 \\
\hline 3. & Typic Udifluvents & Agak Lambat & Sedang & 1,12 & 1.2 & 13,44 & 13,96 & 0,93 \\
\hline 4. & Typic Endoaquepts & Lambat & Sedang & 1,13 & 1.2 & 13,56 & 2,15 & 0,14 \\
\hline 5. & Typic Eutrudepts & Lambat & Dalam & 1,06 & 1.6 & 16,96 & 303,35 & 20,31 \\
\hline 6. & Typic Hapludolls & Sedang & Dalam & 1,20 & 2 & 24,00 & 8,94 & 0,60 \\
\hline 7. & -1 & - & - & - & & - & 60,97 & 4,08 \\
\hline \multirow[t]{2}{*}{8.} & - & - & - & - & & - & 13,25 & 0,89 \\
\hline & & & & & & & 93,881 & \\
\hline
\end{tabular}

Sumber: Hasil Analisis di DAS Wai Ela 2018. 


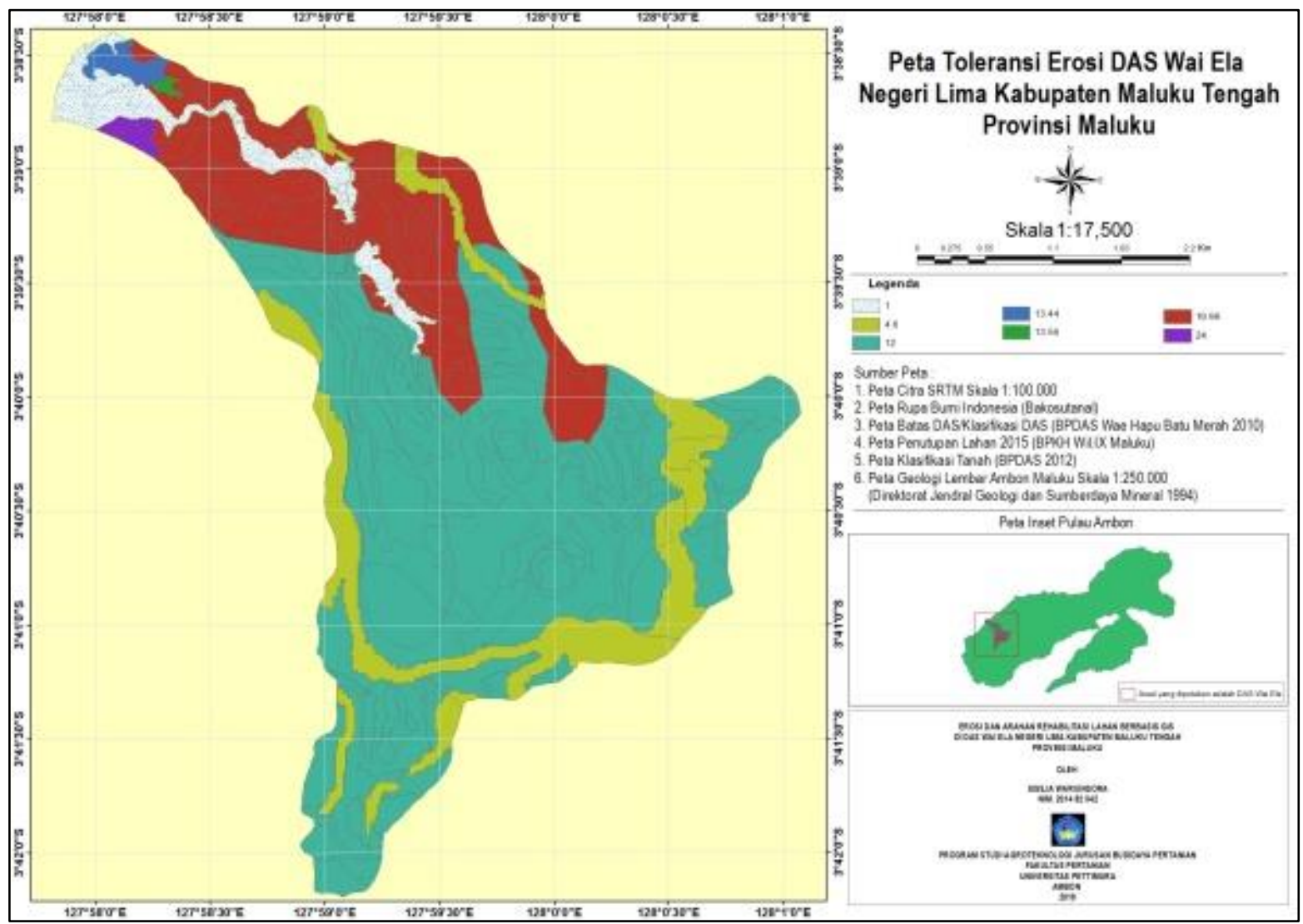

Gambar 9. Sebara nilai T (toleransi erosi) di DAS Wai Ela

3. Pola rehabilitasi lahan pada penggunaan lahan kebun campuran, yaitu penanaman tanaman penutup tanah dengan kerapatan sedang-tinggi untuk kebun campuran yang mempunyai tutupan atas sedang $(\mathrm{CP}$ Maks 0,009-0,033), dan pengkayaan dengan pohon hutan lokal (CP Maks 0,001-0,002).

4. Pola rehabilitasi lahan pada penggunaan lahan pemukiman, yaitu penanaman tanaman penutup tanah dengan berkerapatan tinggi (CP maks 0,033), penanaman rumput dalam strip (CP maks 0,0190,092).

5. Pola rehabilitasi lahan pada penggunaan lahan pertanian lahan kering dan penggunaan lahan terbuka, yaitu penggunaan mulsa (CP maks 0,064), dan penghutanan kembali dengan pohon hutan dan buah-buah lokal.

6. Pola rehabilitasi lahan pada penggunaan lahan pisang, yaitu penanaman tanaman penutup tanah dengan kerapatan sedang (CP maks 0,092).

\section{KESIMPULAN}

Tingkat bahaya erosi di DAS Wai Ela, terdiri atas erosi sangat ringan (rata-rata 8,14 ton/ha/thn) dengan luasan 189,78 ha terdapat pada 11 unit lahan, erosi ringan (rata-rata11,28 ton/ha/thn) dengan luasan 733,06 ha terdapat pada 19 unit lahan, erosi sedang (rata-rata 59,23 ton/ha/thn) dengan luasan 167,70 ha terdapat pada 15 unit lahan, erosi berat $(177,72$ ton/ha/thn $)$ dengan luasan170,11 ha terdapat pada 14 unit lahan, dan erosi sangat berat (rata-rata 38,70 ton/ha/thn) dengan luasan 10,64 ha terdapat pada 6 unit lahan.

Arahan rehabilitasi lahan terdiri dari pengkayaan dengan pohon hutan dan buah-buahan lokal, penamanan tanaman penutup tanah dengan kerapatan sedang-tinggi, penggunaan mulsa, dan penanaman rumput dalam strip.

\section{DAFTAR PUSTAKA}

Ashari, A. 2013. Kajian tingkat erodibilitas beberapa jenis tanah di pengunungan Baturagung desa Putat dan Nglanggeran Kecamatan Patuk Gunung Kidul. Informasi No. 1-XXIX, tahun 2013, 15-31.

Balai Pemantauan Kawasan Hutan Wilayah IX Maluku. 2015. Peta Penutupan Lahan Provinsi Maluku tahun 2015 skala 1:250.000.

Balai Pengelolaan DAS Waehapu Batu Merah. 2012. Peta Tanah dan Penggunaan Lahan DAS Wai Ela skala 1:30.000.

Direktoral Jenderal Geologi dan Sumber Daya Mineral. 1994. Peta Geologi Maluku-Lembar Pulau Ambon skala 1:250.000.

Devatha, C.P., V. Deshpande, and M. Renukaprasad. 2015. Estimation of Soil loss using USLE model for Kulhan Watershed, Chattisgarh. Aquatic Procedia 4 (2015) 1429-1436 International Conference on Water Resources, Coastal and Ocean Engineering (ICWRCOE 2015). 


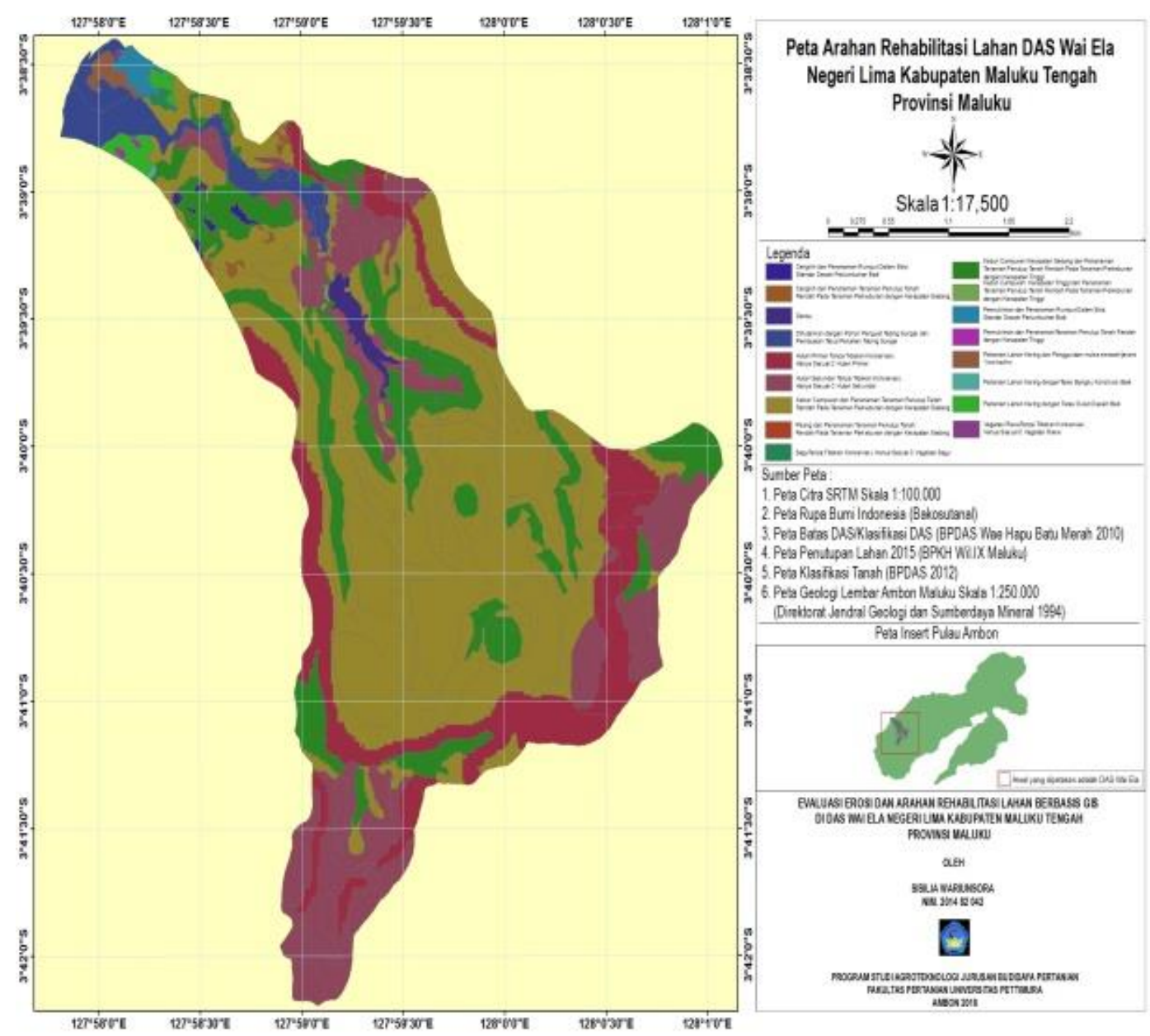

Gambar 10. Peta arahan rehabilitasi lahan DAS Wai Ela

Gelagay, H.S. and A.S. Minale. 2016. Soil loss estimation using GIS and Remote sensing techniques: A case of Koga watershed, Northwestern Ethiopia. International Soil and Water Conservation Research 4: 126-136.

Manuputty, M.P.F. 2017. Evaluasi kualitas dan daya dukung lingkungan DAS Wai Batu Merah Kota Ambon. Tesis, Program Studi Pengelolaan Lahan, Universitas Pattimura.

Mohamadi, M.A. and A. Kavian. 2015. Effects of rainfall patterns on runoff and soil erosion in field plots. International Soil and Water Conservation Research 3: 273-281.

Osok, R.M, S.M. Talakua, dan E.J. Gaspersz. 2018. Analisis faktor-faktor erosi tanah, dan tingkat bahaya erosi dengan metode Rusle di DAS Wai Batu Merah Kota Ambon Provinsi Maluku. Jurnal Budidaya Pertanian 14: 89-96.

Panagos, A., P. Borrelli, K. Meusburger C. Alewell, E. Lugato, and L. Montanarella. 2015. Estimating the soil erosion cover-management factor at the European scale. Land Use Policy 48: 38-50.

Tahir, M.P. 2011. Analisis Tingkat kekritisan Lahan Dan Arahan Penggunaannya Di Daerah Aliran Sungai
Wae Ruhu Kota Ambon. Tesis. Program Studi Pengelolaan Lahan, Program Pascasarjana Universitas Pattimura.

Talakua, S.M. and R.M. Osok. 2019. Development of a land degradation assessment model based on field indicators assessment and prediction methods in Wai Sari, Sub-Watershed Kairatu District, Western Seram Regency, Maluku Province, Indonesia. Science Nature 2: 071-085.

Talakua, S.M. dan R.M. Osok. 2018. Efek penggunaan lahan terhadap degradasi tanah pada kebun campuran di Kecamatan Kairatu Seram Bagian Barat, Maluku. Agrologia 7: 9-16.

Talakua, S.M. dan R.M. Osok. 2017. Pengembangan Model Penilaian Degradasi Lahan Berdasarkan Pendekatan "Field Assessment". Pattimura University Press.

Zhang, H., J. Wei, Q. Yang, J.E.M. Baartman, L. Gai, X. Yang, S. Li, J. Yu, C. J. Ritsema, and V. Geissen. 2017. An improved method for calculating slope length $(\lambda)$ and the LS parameters of the Revised Universal Soil Loss Equation for large watersheds. Geoderma 308: 36-45. 